\title{
Problematika Peraturan Pengganti Undang-Undang Nomor 2 Tahun 2017 tentang Organisasi Masyarakat
}

\section{Rezki Robiatul Aisyiah Ismail}

Pascasarjana Fakultas Hukum Universitas Mulawarman

kyaisyah@yahoo.co.id

\begin{abstract}
Indonesia is a democratic constitutional state set forth in article 1 paragraph (3) of the 1945 Constitution of the State of the Republic of Indonesia, as a legal state for running a state and protection of human rights under the law. One of them is in Article 28 E Paragraph (3) of the 1945 Constitution of the State of the Republic of Indonesia which states that everyone has the right to freedom of association, assembly, and expression. The regulation concerning the Organization of the Community is in fact set out in Law No. 17 of 2013 on Community Organizations. Community organization is an organization founded and formed by the community voluntarily based on the similarity of aspirations, wills, needs, interests, activities and objectives to participate in development in order to achieve the objectives of the Unitary State of the Republic of Indonesia based on Pancasila. Community organizations may be in the form of two, incorporated and non-legal entities.

The Government issued a Regulation in Lieu of Law of the Republic of Indonesia Number 2 Year 2017 on the amendment to Law No. 17 of 2013 on Social Organization and then with the Regulation of Lieu of the Law the government made a policy that the Government in this case gave authority to the Ministry of Justice and Human Rights Asasi Manusia dissolved social organization which contradict with principle of Pancasila one of them is Hizbut Tahrir Indonesia discussion Government Regulation of society organization still has weakness substantially. Government regulation in lieu of laws of community organizations in order to reinforce the principle of contrarius actus is not appropriate because it has actually attached to government officials without the need to be affirmed in the legislation
\end{abstract} Keywords: Government regulation in lieu of law, Community Organization, Contrarius actus

Citation: "Problematika Peraturan Pengganti Undang-Undang Nomor 2 Tahun 2017 tentang Organisasi Masyarakat" Mulawarman Law Review 4, no. 1 (2019)

\section{PENDAHULUAN}

Pengaturan mengenai Organisasi Masyarakat diatur Undang-Undang Nomor 17 tahun 2013 tentang Organisasi Kemasyarakatan. Organisasi masyarakat adalah organisasi yang didirikan dan dibentuk oleh masyarakat secara sukarela berdasarkan kesamaan aspirasi, kehendak, kebutuhan, kepentingan, kegiatan, dan tujuan untuk berpartisipasi dalam pembangunan demi tercapainya tujuan Negara Kesatuan Republik Indonesia 
yang berdasarkan Pancasila. Organisasi masyarakat dapat berbentuk dua, berbadan hukum dan tidak berbadan hukum. ${ }^{1}$

Peraturan pemerintah pengganti undang-undang (Perppu) sebagai pengganti undangundang berdasarkan Undang-Undang Dasar $1945 .^{2} \mathrm{Di}$ Indonesia, kriteria untuk mengeluarkan perppu dalam hal ihwal kegentingan memaksa yang diberlakukan belum diatur dengan jelas. Perppu merupakan hak istimewa yang sepenuhnya merupakan subjektivitas dari Presiden namun ketika menetapkan Perppu tersebut harus memiliki dasar objektivitas agar tidak terdapat unsur penyalahgunaan wewenang dan kekuasaan. Perppu pada dasarnya dibutuhkan oleh penyelenggara negara dan Pemerintah agar negara dapat berjalan dengan baik guna mengatasi permasalahan yang sewaktu-waktu dapat muncul, dan untuk itu diperlukan solusi yang segera dapat dilaksanakan untuk mengisi keadaan yang genting dan memaksa serta perlu diselesaikan seketika itu juga. Perppu bukan suatu alat kekuasaan politik, Perppu merupakan "escape clause" kepada Presiden sebagai pemegang hak subjektif yang dibatasi oleh konstitusi. Presiden tidak boleh mengeluarkan Perppu yang hanya menguntungkan golongannya sendiri atau partai politiknya.

Dinamika sejarah peraturan perundang-undangan di Indonesia menunjukkan bahwa latar belakang penetapan Perppu oleh Presiden umumnya berbeda-beda. Hal ini disebabkan karena kriteria kegentingan yang memaksa selalu bersifat multitafsir dan besarnya subyektivitas Presiden dalam menafsirkan frase kegentingan yang memaksa sebagai dasar untuk menetapkan Perppu. Penulis menilai sangat sulit untuk memberikan tolok ukur yang pasti mengenai kegentingan yang memaksa sebagai dasar penetapan Perppu karena hal itu merupakan hak subyektif Presiden yang memang diamanatkan secara tegas dalam konstitusi, meskipun nantinya diperlukan penilaian obyektif yang dilakukan bersama-sama oleh DPR dan Pemerintah. Menurut Jimly Asshiddiqie, terdapat 3 (tiga) unsur penting yang dapat menimbulkan suatu kegentingan yang memaksa, yakni, (1)Unsur ancaman yang membahayakan (dangerous threat); (2) Unsur kebutuhan yang mengharuskan (reasonable necessity); dan/atau (3) Unsur keterbatasan waktu (limited time) yang tersedia. Unsur ancaman yang membahayakan (dangerous threat) lebih berorientasi pada Pasal 12 UUD NKRI 1945, khususnya mengenai frasa keadaan bahaya, meskipun ada Perppu yang dilatarbelakangi oleh unsur ancaman yang membahayakan (dangerous threat), yakni Perppu Nomor 1 Tahun 2002 tentang Pemberantasan Tindak Pidana Terorisme yang dalam penjelasan Umumnya menegaskan bahwa penggunaan Perppu untuk mengatur pemberantasan tindak pidana terorisme didasarkan pertimbangan bahwa terjadinya terorisme di berbagai tempat telah menimbulkan kerugian baik materiil maupun immateriil serta menimbulkan ketidakamanan bagi masyarakat, sehingga mendesak untuk dikeluarkan perppu supaya segera dapat diciptakan suasana yang kondusif bagi pemeliharaan ketertiban dan keamanan tanpa meninggalkan prinsip-prinsip hukum. Perppu pada dasarnya dibutuhkan pemerintah agar negara dapat berjalan dengan baik guna mengatasi permasalahan yang sewaktu-waktu dapat muncul, dan untuk itu

\footnotetext{
${ }^{1}$ Pasal 1 ayat (1) Undang-Undang Nomor 17 tahun 2013 tentang organisasi kemasyarakatan.

${ }^{2}$ Pasal 22 ayat (1) UUD 1945 menyatakahn bahwa dalam hal ikhwal kegentingan yang memaksa, presiden berhak menetapkan peraturan pemerintah sebagai pengganti undang-undang.
} 
diperlukan solusi yang segera dapat dilaksanakan untuk mengisi keadaan yang genting dan memaksa serta perlu diselesaikan seketika itu juga. Perppu merupakan suatu bentuk penghargaan negara kepada pemerintah, bukanlah suatu alat kekuasaan politik tetapi merupakan "escape clause" kepada Presiden sebagai pemegang hak subjektif yang dibatasi oleh konstitusi.

Pada tanggal 10 Juli 2017 pemerintah mengeluarkan Peraturan Pengganti UndangUndang Republik Indonesia Nomor 2 Tahun 2017 tentang perubahan atas UndangUndang Nomor 17 tahun 2013 tentang Organisasi Kemasyarakatan, dan kemudian dengan Peraturan Pengganti Undang-Undang tersebut pemerintah melakukan kebijakan yakni Pemerintah ingin membubarkan organisasi kemasyarakatan yang bertentangan dengan asas Pancasila salah satunya ialah Hizbut Tahrir Indonesia. Landasan yuridis dari lahirnya peraturan pengganti undang-undang Nomor 2 Tahun 2017 menggunakan Asas Contrarius Actus yang dalam hukum administrasi negara dapat disebut juga sebagai consensus contrarius (tindakan sebaliknya, hukum yang bertentangan) merupakan istilah yuridis, dimana menunjukkan terhadap tindakan sebelumnya (actus primus) yang dibatalkan atau dihapuskan. Contrarius actus memiliki kekuatan hukum yang sama dengan actus primus. ${ }^{3}$ Sebagai contoh, undang-undang hanya dapat diubah atau dicabut dengan tindakan hukum lain, tindakan administratif hanya dapat dibatalkan oleh tindakan administratif lain, dan transaksi hukum hanya dapat diubah dengan transaksi legal lainnya, misalnya perjanjian kontrak dapat dicabut melalui kontrak pencabutan. ketika suatu badan atau pejabat tata usaha Negara menerbitkan keputusan tata usaha negara dengan sendirinya juga (otomatis), badan/pejabat tata usaha yang bersangkutan yang berwenang membatalkannya, dengan adanya Asas Contrarius Actus dalam Perppu Ormas ini, pihak Kementerian Hukum dan Hak Asasi Manusia (Kemenkumham) memiliki kewenangan tak terbatas dalam memberi izin dan mencabut status badan hukum ormas. ${ }^{4}$

Mekanisme pencabutan hak dan kewajiban melekat pada subjek hukum harus dilakukan melalui putusan pengadilan. Contohnya, pencabutan hak dan kewajiban badan hukum lain yang melibatkan lembaga peradilan, seperti pernyataan pailit suatu perseroan terbatas (PT) mesti diajukan ke pengadilan niaga atau pembubaran partai politik melalui putusan Mahkamah Konstitusi (MK). Konsekuensi perubahan status badan hukum tersebut berimplikasi organisasi masyarakat tidak diizinkan melakukan kegiatan apapun secara sepihak. Sebab, pengambilan keputusan penghentian segala aktivitas kegiatan organisasi masyarakat dilakukan tidak secara objektif dan diimbangi dengan otoritas lembaga yudikatif. Sehingga potensi diskresi yang sewenang-wenang dalam melakukan penghentian kegiatan organisasi masyarakat. Kemudian, pada Pasal 62 ayat (3) Perppu Ormas meniadakan prosedur hukum pencabutan status badan hukum suatu ormas melalui pengadilan. Secara garis besar, penerapan Asas Contrarius Actus ini di gunakan dalam konteks rezim izin, yang dimaksud dari rezim izin ini sendiri adalah sesuatu yang dilarang atau illegal dapat menjadi legal apabila mendaptkan izin dari pejabat yang memiliki wewenang. Sementara dalam kehidupan

\footnotetext{
${ }^{3}$ M.Lutfhi Chakim, http://www.lutfichakim.com/2017/09/contrarius-actus.html, Diakses tanggal 13 Desember 2017, Pukul. 18.00 WITA.

${ }^{4}$ Ibid.
} 
berdemokrasi rakyat indonesia dijamin oleh konstitusi atas kebebasan. Kajian ini akan membahas frasa kegentingan yang memaksa dlam sistem demokrasi dan penerapan asas Contrarius Actus berdasarkan Perppu Nomor 2 Tahun 2017.

\section{Perspektif Kegentingan yang Memaksa dalam Pembentukan Peraturan Pengganti Undang-Undang Nomor 2 Tahun 2017}

Di indonesia aspek keadaan darurat merupakan salah satu syarat dikeluarkannya Perppu sehingga terdapat kegentingan yang memaksa presiden untuk mengeluarkan suatu aturan hukum yang berfungsi mencegah terjadinya kekacauan yang diakibatkan oleh kekosongan hukum yang mengatur restriksi mengenai suatu penyimpangan yang dikhawatirkan akan berdampak kerusakan secara luas di masyarakat. Hal ini mengacu kepada konstirusi Pasal 22 ayat (1). Jika merujuk pada Risalah Sidang Badan Penyidik Usaha-Usaha Persiapan Kemerdekaan Indonesia (BPUPKI), maka tidak ditemukan adanya pembahasan yang mendalam mengenai konsep perppu. Pengaturan Perppu Pasal 22 UUD hanya sempat di singgung dalam Sidang Pertama Panitia Persiapan Kemerdekaan Indonesia (PPKI) pada 18 Agustus $1945 .^{5}$ Walaupun bagian Penjelasan UUD 1945 telah mencoba mengurai frasa kegentingan yang memaksa, akan tetapi sebenarnya indikator dari kegentingan yang memaksa tidak cukup jelas. UUD 1945 hanya menunjukan ciri kegentingan tersebut melalui ketentuan di ayat (2) yang menyatakan bahwa perppu harus mendapat persetujuan Dewan Perwakilan Rakyat (DPR) dalam persidangan yang berikut. Kegentingan yang memaksa secara harafiah hanya dapat didefinisikan sebagai kondisi yang tidak normal, tetapi tidak mampu menjelaskan kondisi kegentingan yang memaksa dalam indikator yang terukur. ${ }^{6}$ Lemahnya kegentingan karena tanpa indikator yang jelas dapat dilihat pada jumlah perppu pada tahu 1960 (pasca-dekrit presiden) yang mencapai 56 judul. Jumlah perppu tersebut dapat menyiratkan adanya keadaan genting atau justru kondisi sebaliknya, yaitu kriteria yang kabur sehingga pemerintah dapat menafsirkannya

5 Pada Sidang Tersebut, Otto Iskandardinata mengklarifikasi pengaturan perppu “jadi peraturan Pemerintah itu harus mendapat persetujuan Dewan Perwakilan akyat dalam sidangnya. Dalam prakteknya presiden akan ditunjuk. Nanti persiden harus mengadakan peraturan yang harus disahkan oleh Dewan Perwakilan Rakyat yang belum kita bentuk. Bagaimana dalam hal ini?". Terhadap pertanyaan tersebut, soepomo memberikan jawaban singkat bahwa hal tersebut sudah termasuk dalam peraturan peralihan. ${ }^{5}$ Tidak adanya dinamika pembahasan konsep perppu dalam sidang BPUPKI dan PPKI menunjukkan bahwa tidak ada elaborasi yang mendalam terhadap konsep tersebut. Pemahaman terhadap konsep perppu dapat dilihat pada bagian Penjelasan UUD 1945 sebelum amandemen. Pasal 22 yang mengatur konsep perppu merupakan salah satu pasal dalam UUD 1945 yang tidak mengalami amandemen. Oleh karena itu, walaupun bagian Penjelasan UUD 1945 telah dihapus dalam amandemen tetapi penjelasan frasa kegentingan yang memaka masih dapat ditelusuri pada bagian penjelasan tersebut maupun gagasan yang melatarbelakanginya. Penjelasan pasal 22 UUD 1945 (sebelum amandemen), menjelaskan sebagai berikut: Pasal ini mengenai noodverordeningsrecht Presiden. Aturan sebagai ini memang perlu diadakan agar supaya keselamatan negara dapat dijamin oleh pemerintah dalam keadaan yang genting, yang memaksa pemerintah untuk bertindak lekas dan tepat. Meskipun demikian, pemerintah tidak akan terlepas dari pengawasan Dewan Perwakilan Rakyat. Oleh karena itu, peraturan dalam pasal ini, yang kekuatannya sama dengan undang-undang yang harus disahkan pula oleh Dewan Perwakilan Rakyat.

${ }^{6}$ Reza Fikri Febriansyah, Eksistensi dan prospek pengaturan perppu dalam sistem norma hukum negara republic indonesi, jurnal legislasi indonesia, vol 8, No.4. 2012, hlm 670 
secara luas. ${ }^{7}$ Presiden di dalam proses pengusulan perppu tidak halnya sesuai kehendaknya, namun harus sesuai dengan prosedur yang sesuai dengan undangundang, karena perppu pada hakikatnya hanya dibentuk oleh DPR yang seyogyanya memperhatikan prasyarat yang tertulis dalam peraturan perundang-undangan, sehingga perppu yang dikeluarkan ini nantinya akan sah secara konstistusional. Perppu disebutkan dalam Pasal 22 ayat (1) Undang-Undang Dasar 1945 (UUD 1945) selain itu penetapan perppu yang dilakukan oleh Presiden ini juga tertulis dalam Pasal 1 angka 4 Undang-undang No. 12 Tahun 2011 tentang Pembentukan Peraturan Perundangundangan namun tidak berarti bahwa secara absolute tergantung kepada penilaian subjektif Presiden karena sebagai parameter adanya kegentingan yang memaksa. ${ }^{8}$ Indikator kegentingan yang memaksa kemudian dirumusankan Mahkamah Konstitusi (MK) tentang tentang permohonan pengujian perppu no 4 Tahun 2009 tentang perubahan atas undang-undang nomor 30 tahun 2002 tentang komisi pemberantasan tindak pidana terhadap UUD 1945 yang diucapkan dalam sidang pleno terbuka pada hari senin, 8 februari 2010 (putusan sidang MK No 138/PUU-VII/2009) menjelaskan persyaratan keadaan kegentingan yang memaksa dalam tiga hal, yaitu, (1) Adanya keadaan yaitu kebutuhan mendesak untuk menyelesaikan masalah hukum secara cepat berdasarkan undang-undang; (2)Undang-undang yang dibutuhkan tersebut belum ada sehingga terjadi kekosongan hukum, atau ada undang-undang tetapi tidak memadai; (3) Kekosongan hukum tersebut tidak dapat diatasi dengan cara membuat undang-undang secara prosedur biasa karena akan memerlukan waktu yang cukup lama sedangkan keadaan yang mendesak tersebut perlu kepastian untuk diselesaikan. Pendapat Mahkamah Konstitusi tidak berbeda dengan pendapat jimmly Asshiddiqie mengenai unsur penting kegentingan yang memaksa. Menurut Jimmly Asshiddiqie, kegentingan yang memaksa sebagai syarat perppu memiliki tiga syarat yaitu ancaman yang membahayakan, kebutuhan yang mengharuskan, dan/atau keterbatasan waktu. ${ }^{9}$ Menurut Jimly Asshiddiqie, kedudukan perppu sebagai norma subjektif dalam Pasal 22 memberikan kewenangan kepada presiden untuk secara subjektif menilai keadaan negara atau hal ihwal yang terkait dengan negara yang menyebabkan suatu undangundang tidak dapat dibentuk segera, sedangkan kebutuhan akan pengaturan materiil mengenai hal yang perlu diatur sudah sangat mendesak sehingga Pasal 22 UUD 1945 memberikan kewenangan kepada presiden untuk menetapkan Perppu. Binsar Gultom memiliki pendapat berbeda dengan Jimmly Asshiddiqie, menurut Binsar Gultom perppu tidak menyaratkan adanya ancaman yang membahayakan. Kriteria kegentingan yang memaksa dalam pembentukan perppu lebih menekankan aspek kebutuhan yang mengharuskan (reasonable necessity), dan/atau keterbatasan waktu (limited time). Oleh karena itu, pembentukan perppu menurut gultom tidak menyaratkan adanya keadaan bahaya (dangerous threats), baik yang diumumkan

7 Relativitas kegentingan dalam perspektif pemerintah dapat ditemukan pada peraturan pemerintah pengganti undang-undag nomor 5 tahun 1963 tentang surat hutang landreform. Perppu tidak pernah efektif dilaksanakan saat itu dan juga sekarang karena undang-undang tersebut belum pernah dicabut atau diganti oleh undang-undang lain

${ }^{8}$ Putusan Mahkamah Konstitusi nomor 138/PUU-VII/2009

9 Jimmly Asshiddiqie, Hukum Tata Negara Darurat, PT. Rajagrafindo Persada, 2007, hlm. 207- 
secara resmi maupun tidak diumumkan. ${ }^{10}$ Hal ikhwal kegentingan yang memaksa, presiden harus sigap dan bertindak cepat untuk mengatasi keadaan, karena apabila dilakukan pembahasan Rancangan Undang-Undang (RUU) dengan DPR untuk mengatasi keadaan yang memaksa akan membutuhkan waktu yang cukup lama.

Kegentingan yang memaksa merupakan keadaan darurat yang tidak hanya terbatas pada ancaman bahaya atas keamanan, keutuhan negara, atau ketertiban umum. Tapi juga hal-hal yang dapat mengganggu stabilitas negara misalnya krisis ekonomi, bencana alam. Dalam Perppu Nomor 2 Tahun 2017 ada dua hal pokok yang diklaim sebagai kegentingan yang memaksa diterbitkannya perppu. Pertama, bahwa UndangUndang Nomor 17 Tahun 2013 tentang organisasi kemasyarakatan mendesak untuk segera dilakukan perubahan karena belum mengatur secara komperhensif mengenai keormasan yang bertentangan dengan pancasila dan Undang-Undang Dasar Negara Republik Indonesia Tahun 1945 sehingga terjadi kekosongan hukum dalam hal penerapan sanksi yang efektif. ${ }^{11}$ Kedua, bahwa Undang-Undang Nomor 17 Tahun 2013 tentang Organisasi kemasyarakatan belum menganut asas contrarius actus sehingga tidak efektif untuk menerapkan sanksi terhadap organisasi kemasyarakatan yang menganut, mengembangkan, serta menyebarkan ajaran atau paham yang bertentangan dengan pancasila dan Undang-Undang Dasar Negara Republik Indonesia Tahun $1945^{12}$ Terhadap alasan yang pertama bahwa yang dimaksud frasa belum mengatur secara komperhensif adalah ketentuan Pasal 59 ayat (4) Undang -undang ormas yang mengatur pengertian tentang pelarangan menganut, mengembangkan, serta pengertian ajaran yang bertentangan dengan pancasila karenanya tidak dapat dikatakan sanksi. Latar Belakang ini lah dianggap kegentingan yang memaksa oleh presiden, sehingga perlu perppu untuk meredefinisikan terhadap ajaran yang bertentangan pancasila. Pasal 59 Huruf c Perppu nomor 2 Tahun 2017 menyatakan, yang dimaksud dengan ajaran atau paham yang bertetangan dengan pancasila, antara lain ajaran atheism, komunisme, marxisme, leninisme, atau paham lain yang bertujuan mengganti, mengubah Pancasila dan Undang-Undang Dasar Negara Tahun 1945. Perluasan makna melalui perppu terhadap defnisi ajaran atau paham yang bertentangan dengan pancasila, pada intensinya adalah untuk mengisi kekosongan hukum guna kepastian hukum. Apabila kita perhatikan bersama dengan teliti frasa atau paham lain yang bertujuan mengganti, mengubah Undang-Undang Dasar Tahun 1945, maka sulit kepastian hukum akan tercapai. Alasannya adalah frasa tersebut memiliki definisi yang sangat luas dan multitafsir, karena frasa tersebut jika dibaca dari sudut pandang apapun akan menyebar kecemasan karena akan bermakna siapapun ormas yang menganut paham yang bertujuan untuk mengubah Undang-Undang Dasar Tahun 1945, maka dapat dikenakan sanksi. ${ }^{13}$ Jika kita dapat mengambil contoh ormas pusat studi konstitusi yang tujuan di bentuknya adalah untuk melakukan kajian

${ }^{10}$ Binsar Gultom, Pelanggaran HAM dalam hukum keadaan darurat di indonesia; mengapa pengadilan HAM Ad Hoc di Indonesia kurang efektif?, Jakarta: PT. Gramedia Pustaka Utama, 2010. HIm. 116-117

${ }^{11}$ Konsideran huruf c Perppu Nomor 2 tahun 2017

12 Konisderan huruf e Perppu Nomor 2 tahun 2017

${ }^{13}$ Pendapat Ahli dalam Pemohonan Perkara Nomor 39/PUU-XV/2017 , Irman Putera Sidin. 
konstitusi yang kemudian juga bertujuan memperbaiki kelemahan di dalam UndangUndang Dasar Tahun 1945. Pada umumnya, Pusat studi konstitusi membuat rekomendasi untuk mengganti atau mengubah konstitusi yang pasti di dalam ormas tersebut ada yang menganut paham federaisme, unitarisme, utilitarianisme, republikanisme dan paham konstitusionalisme hingga absolutism. ${ }^{14}$ Substansi Perppu dalam kaitannya dengan argumentasi ini menambahkan dua materi larangan terhadap ormas, yaitu, (1) Larangan menggunakan nama, lambang, bendera, atau simbol organisasi yang sama (pada pokok atau keseluruhan) dengan nama, lambang, bendera , atau simbol organisasi gerakan separatis atau terlarang; (2) Larangan melakukan kegiatan separatis yang mengancam kedaulatan NKRI.

Dalam substansinya Perppu tersebut menambahkan bagian penjelasan Pasal 59 untuk memperjelas ruang lingkup larangan melakukan tindakan permusuhan terhadap suku, agama, ras, atau golongan dan menganut, mengembangkan, serta menyebarkan ajaran atau paham perppu mencakup ucapan, pernyataan, sikap atau aspirasi (lisan dan tertulis) melalui media ektronik atau non-elektronik yang menimbulkan kebencian terhadap kelompok tertentu, setiap orang, dan penyelenggara negara. Larangan terhadap paham yang bertentangan dengan Pancasila juga diperluas, sehingga bukan hanya mencakup ajaran ateisme, komunisme/ Marxism-Leninisme, tetap juga paham lain yang bertujuan mengganti/ mengubah Pancasila dan UUD 1945. Perluasan larangan permusuhan sehingga mencakup pula permusuhan terhadap penyelenggara negara menuai keritik karena berpotensi mengkriminalisasi pihak-pihak yang mengkritik pemerintah. Pandangan kontra tersebut sebenarnya terbuka untuk diperdebatkan karena aspek materiil dalam unsur 'menimbulkan kebencian' dan sikap anti-pemerintah yang sebenarnya menjadi sasaran dari perppu ini. Kelemahan dari perluasan larangan permusuhan terebut justru pada aspek perancangan drafting bagian penjelasan. Padahal, dalam Undang-Undang Nomor 12 Tahun 2011 tentang pembentukan Peraturan Perundang-undangan membatasi materi muatan yang dapat dicantumkan dalam bagian penjelasan. Penjelasan seharusnya tidak boleh mencantumkan rumusan yang berisi norma dan rumusan yang isinya memuat perubahan terselubung terhadap ketentuan peraturan perundang-undangan. Pasal 59 ayat (3) sebenarnya merumuskan sasaran dari tindakan permusuhan adalah suku, agama, ras, atau golongan. Oleh karena itu, bagian penjelasan seharusnya memberikan tafsiran terhadap istilah tindakan permusuhan suku, agama, ras, gologan namun substansi penjelasan justru memperluas makna dari norma Pasal 59 ayat (3) yang menjelaskan bahwa Yang dimaksud dengan 'tindakan permusuhan' adalah ucapan, pernyataan, sikap atau aspirasi, baik secara lisan maupun tertulis, baik melalui media elektronik maupun tidak melalui media elektronik yang menimbulkan kebencian, baik terhadap kelompok tertentu maupun terhadap setiap orang termasuk ke penyelenggara negara. Sehingga dapat kita lihat bahwa penyelenggara negara menjadi bagian dari sasaran tindakan permusuhan.

${ }^{14}$ Ibid. 
Penerapan Asas Contrarius Actus Sebagai Landasan Yuridis di Terbitkannya Peraturan Pengganti Undang-Undang Nomor Tahun 2017 Dalam Perspektif Hukum Administrasi Negara

Pada tanggal 10 Juli 2017 Pemerintah menerbitkan Peraturan Pemerintah Pengganti Undang-Undang (Perppu) Nomor 2 Tahun 2017 tentang Perubahan atas UndangUndang Nomor 17 Tahun 2013 tentang Organisasi Kemasyarkatan (Ormas). Landasan yuridis dalam menerbitkan Perppu ini adalah penggunaan asas contrarius actus, norma hukum perppu ormas didasarkan pada faktor sosial, politik dan yuridis yang dapat ditemukan pada bagian konsideran. Salah satu yang menjadi landasan yuridis adalah Undang-Undang Organisasi Masyarakat belum menganut asas contrarius actus sehingga tidak efektif untuk menerapkan sanksi terhadap ormas yang menganut, mengembangkan, serta menyebarkan ajaran atau paham yang bertentangan dengan pancasila dan UUD 1945. Sebagaimana yang telah tercantum dalam konsideran menimbang huruf e Perppu yang menyatakan: ${ }^{15}$ Bahwa Undang-Undang Nomor 17 Tahun 2013 tentang Organisasi Kemasyarakatan belum menganut asas contrarius actus sehingga tidak efektif untuk menerapkan sanksi terhadap organisasi kemasyarakatan yang menganut, mengembangkan, serta menyebarkan ajaran atau paham yang bertentangan dengan Pancasila dan Undang-Undang Dasar Negara Republik Indonesia Tahun 1945. Asas contrarius actus atau dapat disebut juga sebagai consensus contrarius (tindakan sebaliknya, hukum yang bertentangan) merupakan istilah yuridis, dimana menunjukkan terhadap tindakan sebelumnya (actus primus) yang dibatalkan atau dihapusan. Contrarius actus memiliki kekuatan hukum yang sama dengan actus primus. Sebagai contoh, undang-undang hanya dapat dibatalkan oleh tindakan administrasi lain, dan transaksi hukum hanya dapat di ubah dengan transaksi legal lainnya. Misalnya, perjanjian kontrak dapat dicabut melalui kontrak pencabutan. ${ }^{16}$

Asas contrarius actus dalam hukum administrasi negara adalah asas yang menyatakan badan atau pejabat tata usaha negara yang menerbitkan keputusan tata usaha negara dengan sendirinya juga berwenang untuk membatalkannya. ${ }^{17}$ Asas contrarius actus sebenarnya melekat pada pejabat pemerintah tanpa perlu ditegaskan dalam peraturan perundang-undangan. Sebenarnya setiap pejabat pemerintah dapat menarik kembali keputusan yang dibuatnya walaupun wewenang tersebut tidak disebutkan secara ekplisit dalam peraturan perundang-undangan yang terkait, dalam konteks ini adalah Perppu Ormas. Secara umum, asas contrarius actus telah tercantum secara eksplisit dalam Pasal 33 ayat (3) Undang-Undang Nomor 30 Tahun 2014 tentang Administrasi Pemerintahan. ${ }^{18}$ Pencabutan kembali suatu keputusan juga harus mengacu pada

\footnotetext{
${ }^{15}$ Peraturan Pemerintah Pengganti Undang -Undang Nomor 2 Tahun 2017 tentang Perubahan atas Undang-Undang Nomor 17 Tahun 2013 Tentang Oeganisasi Kemasyarakatan

${ }^{16}$ Luthfi Chakim, Contrarius Actus, Rubrik Kamus Hukum Majalah Konstitusi edisi No.126 Agustus 2017.

${ }^{17}$ Philipus. M. Hadjon, Titiek Sri Djatmiati, Argumentasi Hukum, Gajah Mada University Press, 2005, hlm 83

18 Pencabutan Keputusan atas penghentian Tindakan sebagaimana dimaksud pada ayat (2) wajib dilakukan oleh (a)Badan dan/atau Pejabat Pemerintahan yang mengeluarkan Keputusan dan/atau
} 
kriteria atau batasan yang telah diatur dalam Undang-Undang Administrasi Pemeritahan, yaitu apabila ada cacat wewenang, prosedur, dan/atau substansi (Pasal 64 UU Administrasi Pemerintahan). Alasan pencabutan status badan hukum ormas dalam konteks ormas radikal dapat digolongkan dalam kriteria cacat substansi, salah satunya, salah satunya, jika keputusan yang dikeluarkan ternyata dapat membahayakan dan merugikan kepentingan umum. Berdasarkan hal itu maka keududkan Perppu Ormas dalam rangka mempertegas asas contrarius actus secara normatif tidak tepat. Perppu tersebut secara substansial justru lebih di tunjukan untuk memperjelas ruang lingkup membahayakan dan merugikan kepentingan umum dalam konteks keormasan. Salah satu bentuknya adalah memberikan definisi-definisi yang lebih tegas terhadap ruang lingkup larangan bagi ormas.

Asas contrarius actus yang menjadikan landasan yuridis lahirnya Perppu Nomor 2 tahun 2017 tentang perubahan Undang-Undang Nomor 17 Tahun 2013 tentang organisasi kemasyarakatan, telah dianut oleh Undang-Undang Nomor 17 Tahun 2013 Tentang organisasi kemasyarakatan, karena seperti yang telah di atur dalam pasal tersebut, pemerintah c.q menteri urusan pemerintahan di bidang hukum dan HAM, dapat melakukan sanksi pencabutan. Kemudian yang membedakan Undang-Undang Nomor 17 Tahun 2013 dengan Perppu Nomor 2 Tahun 2017 dalam konteks pencabutan keputusan adalah dihilangkannya peran kekuasaan kehakiman, Melihat Perppu ormas dalam aspek hukum, terjadi kejanggalan supremasi hukum dimana pemerintah melucuti proses hukum yang telah ditetapkannya sendiri sehingga pemerintah terkesan mengabaikan supremasi hukum yang berlaku di Indonesia. Dalam UU No. 17 Tahun 2013 disebutkan bahwa proses pembubaran ormas harus melalui putusan pengadilan, dan dengan proses hukum tertentu. Namun pasal-pasal yang mengatur jalannya supremasi hukum terhadap ormas yang dianggap melakukan pelanggaran kemudian dihapus oleh pemerintah melalui Perppu ormas. Hal ini mengakibatkan supremasi hukum terhadap ormas yang melanggar terkesan pincang. Secara tidak langsung, pemerintah mengambil kewenangan lembaga yudikatif yang dalam hal ini adalah Mahkamah Agung yang sebelumnya memiliki wewenang untuk memutuskan perkara terhadap ormas yang dianggap melakukan pelanggaran. Sehingga pemerintah terkesan menjadi rezim yang diktator karena melakukan pembubaran ormas secara sepihak dengan tidak disertai bukti-bukti yang seharusnya dapat dipaparkan di pengadilan. Pemerintah juga mengabaikan asas praduga tak bersalah, sehingga ormas yang dianggap melakukan pelanggaran tidak mempunyai hak untuk melakukan pembelaan di depan pengadilan. Hal ini dapat dilihat sebagai penyimpangan terhadap konsep pemisahan kekuasaan di negara yang demokratis, dimana masing-masing lembaga mempunyai kontrol dan kewenangannya masingmasing. Secara tidak langsung keputusan pemerintah tersebut mencederai demokrasi. Kewenangan yang dimiliki pemerintah saat ini dapat dikatakan melangkahi lembaga yudikatif, sehingga ini merupakan bentuk penyimpangan demokrasi dimana pemerintah melemahkan kekuasaan lembaga yudikatif yang dalam hal ini adalah Mahkamah Agung yang padahal kewenangan lembaga yudikatif merupakan

Tindakan atau;(b) Atasan Badan dan/atau atasan Pejabat yang mengeluarkan Keputusan dan/atau tindakan pabila pada tahap penyelesaian dengan upaya administrasi. 
keniscayaan konstitusi sehingga Perppu ini membuka peluang untuk pemerintah berbuat sewenang-wenang untuk membubarkan ormas yang secara subyektif dianggap pemerintah bertentangan dengan Pancasila tanpa melalui proses pengadilan maka lahirnya perppu ormas bukan dalam rangka injeksi asas contrarius actus, tetapi dalam rangka menyederhanakan proses pembubaran ormas dengan menegasikan peran kekuasaan kehakiman c.q negara hukum Pasal 1 ayat (3) Undang-Undang Dasar Tahun 1945 Pasal 24 dan 24A Undang-Undang Dasar Tahun $1945 .{ }^{19}$ Seandainya dikatakan bahwa Undang-Undang Ormas belum terinjeksi asas contrarius actus, maka pada umumnya asas hukum tidak di tuangkan dalam bentuk peraturan yang konkret atau pasal-pasal, akan tetapi tidak jarang asas hukum itu dituangkan dalam peraturan konkret. ${ }^{20}$ Jika sepaham dengan ini, maka tidak dianutnya asas contrarius actus tidak bisa dijadikan alasan kegentingan yang memaksa, dengan begitu seharusnya pemerintah harus mengikuti proses formal legislasi bersama DPR karena tidak semua asas dapat dijadikan kegentingan yang memaksa untuk segera mutlak dituangkan dalam peraturan konkret.

Ddalam pertimbangannya, pemerintah menerapkan asas contarius actus dalam perppu nomor 2 tahun 2017, asas tersebut secara singkat menjelaskan bahwa lembaga yang mengeluarkan izin atau memberikan pengesahan terhadap ormas juga berwenang membatalkannya, penerapan asas tersebut menunjukkan bahwa pemerintah tidak paham mengenai perbedaan antara izin dan pengesahan. Menurut Mustafa Fakhri, Pusat Studi Tata Negara Fakultas Hukum Universitas Indonesi, dalam penerbitan izin, pemberi izin dapat serta merta mencabut izin dengan syarat tertentu. Namun, khusus untuk pengesahan, kecuali ada syarat formil yang dapat membatalkan pengesahan tidak dapat serta merta mencabutnya, apalagi menggunakan tafsir subjektif pemerintah. ${ }^{21}$ Kemudian, logika yang digunakan pemerintah dengan menggunakan asas contrarius actus tersebut sangat berpotensi juga di gunakan untuk jenis badan hukum lainnya yang membutuhkan pengesahan dari pemerintah seperti Yayasan dan Perseroan Terbatas, sehingga kewenangan presiden dalam membentuk perppu ormas ini dapat disalahgunakan untuk menghidupkan kembali rezim otoritarianisme baru dan mengancam kehidupan berdemokrasi di Indonesia. Apabila kita meneliti melalui pendekatan kasus, pembubaran ormas HTI ini memiliki kemiripan dengan situasi pada tahun 1959. Pada waktu itu pemerintah memiliki target membubarkan dua partai salah satunya ialah Partai Masyumi. Pemerintah pada saat itu melakukan segala cara untuk membubarkan Masyumi termasuk dengan menafsirkan Pancasila secara monolitik yakni harus sejalan dengan konsep Nasakom (nasionalis, agama dan komunisme). Hal tersebut berlanjut dengan ditetapkannya Penetapan Presiden nomor 7 tahun 1959 tentang syarat-syarat penyederhanaan kepartaian yang mengatur

19 Pendapat Ahli Irman Putra Sidin dalam pengujian Peraturan Pemerintah Pengganti UndangUndang Nomor 2 tahun 2017 tentang Perubahan atas Undang-Undang Nomor 17 tahun 2013 tentang Organisasi Kemasyarakatan, pengujian materiil Peraturan Pemerintah Pengganti Undang-Undang Nomor 2 Tahun 2017 tentang Perubahan atas Undang-Undang Nomor 17 Tahun 2013 tentang Organisasi Kemasyarakatan, pengujian formil dan materiil Peraturan Pemerintah Pengganti Undang-Undang Nomor 2 Tahun 2017 tentang Perubahan atas Undang-Undang Nomor 17 Tahun 2013 tentang Organisasi Kemasyarakatan terhadap Undang-Undang Dasar Negara Republik Indonesia Tahun 1945.

${ }^{20}$ Sudikno Mertokusumo, Mengenal Hukum Suatu Pengantar, liberty, Yogyakarta 2005, hlm 67 
tentang syarat-syarat pembubaran partai politik namun yang menjadi perbedaan antara pembubaran ormas terdahulu yakni masyumi dengan pembubaran ormas yang sekarang dilakukan pemerintah terhadap HTI memiliki perbedaan dalam mekanisme pembubarannya, seperti yang sudah di jelaskan bahwasanya dalam mekanisme pembubaran ormas HTI dengan menggunakan perppu, pemerintah mengambil kewenangan lembaga yudikatif dalam hal ini adalah Mahkamah Agung yang sebelumnya memiliki wewenang untuk memutuskan perkara terhadap ormas yang dianggap melakukan pelanggaran. Berbeda dengan mekanisme pembubaran masyumi, saat itu dengan ditetapkannya Penetapan Presiden nomor 7 tahun 1959 yang kemudian berlanjut dengan di keluarkannya keputusan Presiden Republik Indonesia Nomor 200 Tahun 1960 pemerintah tidak menghilangkan peran lembaga yudikatif,yakni, Mahkamah Agung, hal tersebut dapat kita lihat pada Penetapan Presiden dan Keputusan Presiden dalam hal mendengar Mahkamah Agung Republik Indonesia.

\section{PENUTUP}

Dalam sistem demookrasi Inodnesia maka Perppu Ormas justru memberikan pembatasan terhadap kebebasan. Hal ini akan berakibat pada minimnya diskursus deliberative di ruang publik. Pembuatan Perppu tidak boleh sewenang-wenang agar tidak terjadi konflik antar lembaga tinggi negara, sehingga parameter penerbitan Perppu dalam hal ihwal kegentingan memaksa harus benar-benar diterapkan dengan baik dengan memperhatikan syarat umum dan syarat khusus. Presiden dalam subyektifitasnya menentukan hal ikhwal kegentingan memaksa untuk menerbitkan Perppu hendaknya juga mematuhi konstitusi normatif pada pasal-pasal UUD Tahun 1945 yang mengatur mengenai HAM.Dalam substansinya Perppu ini juga menambahkan bagian penjelasan Pasal 59 yang memberikan perluasan ruang lingkup larangan. Padahal, dalam Undang-Undang Nomor 12 Tahun 2011 tentang pembentukan Peraturan Perundang-undangan membatasi materi muatan yang dapat dicantumkan dalam bagian penjelasan. Penjelasan seharusnya tidak boleh mencantumkan rumusan yang berisi norma dan rumusan yang isinya memuat perubahan terselubung terhadap ketentuan peraturan perundang-undangan. Perppu ormas dalam rangka mempertegas asas contrarius actus tidak tepat karena asas hukum (dalam konteks ini adalah contrarius actus) sebenarnya telah melekat pada pejabat pemerintah tanpa perlu di tegaskan dalam peraturan perundang-undangan. Undang-Undang Nomor 17 Tahun 2013 tentang ormas sesungguhnya telah menganut asas contrarius actus, dalam pasal 67 ayat (1) dan 68 Undang-Undang Nomor 17 Tahun 2013 tentang ormas. Asas contrarius actus tidak bisa diterapkan untuk ormas, asas tersebut hanya berlaku untuk hal yang bersifat administratif.

\section{DAFTAR PUSTAKA}

Binsar Gultom, Pelanggaran HAM dalam hukum keadaan darurat di indonesia; mengapa pengadilan HAM Ad Hoc di Indonesia kurang efektif?, Jakarta: PT. Gramedia Pustaka Utama, 2010. 
Jimmly Asshiddiqie, Hukum Tata Negara Darurat, PT. Rajagrafindo Persada, 2007

Luthfi Chakim, Contrarius Actus, Rubrik Kamus Hukum Majalah Konstitusi edisi No.126 Agustus 2017

Penetapan Presiden Republik Indonesia Nomor 7 Tahun 1959 tentang syaratsyarat dan Penyederhanaan kepartaian

Peraturan Pemerintah Pengganti Undang -Undang Nomor 2 Tahun 2017 tentang Perubahan atas Undang-Undang Nomor 17 Tahun 2013 Tentang Oeganisasi Kemasyarakatan

Philipus. M. Hadjon, Titiek Sri Djatmiati, Argumentasi Hukum, Gajah Mada University Press, 2005,

Reza Fikri Febriansyah, Eksistensi dan prospek pengaturan perppu dalam sistem norma hukum negara republic indonesi, jurnal legislasi indonesia, vol 8, No.4. 2012

Sudikno Mertokusumo, Mengenal Hukum Suatu Pengantar, liberty, Yogyakarta 2005,

Undang-Undang Nomor 12 Tahun 2011 tentang Pembentukan Peraturan Perundang-undangan. 